\title{
EVALUATION OF THE IMPLEMENTATION AND ADHERENCE TO THE CLINICAL PATHWAY OF ISCHEMIC STROKE AT MUHAMMADIYAH GAMPING HOSPITAL, YOGYAKARTA
}

\author{
Dhanis Ardian Prasetyo, Sri Sundari, Ekorini Listyowati
}

Masters Program in Hospital Management, Universitas Muhammadiyah Yogyakarta

\begin{abstract}
Background: Stroke is the second leading cause of death and the third leading cause of disability-adjusted life-years (DALYs) worldwide. The effects of a stroke are the result of damage to the brain that occurs when there is a lack of blood supply to any region of the brain. This study aimed to evaluate the implementation and adherence to the clinical pathway of ischemic stroke at Muhammadiyah Gamping Hospital, Yogyakarta.

Subjects and Method: This study was a mixed method carried out at Muhammadiyah Gamping Sleman Hospital, Yogyakarta. A sample of informants was selected for this study, consisting of neurosurgeons, medical committee members, and ischemic stroke patients. The study theme was implementation of clinical pathway of ischemic stroke. The data were obtained from medical record and interview. The data were analyzed by quantitative and qualitatively.

Results: As much as 52.8\% of the ischemic stroke clinical pathway had been well implemented. Only about $26.4 \%$ of the neurosurgeons complied with the clinical pathway of ischemic stroke.

Conclusion: Ischemic stroke clinical pathway is only partially implemented. Only a few neurosurgeons complied with the clinical pathway.

Keywords: ischemic stroke, clinical pathway, implementation, compliance.

\section{Correspondence:}

Dhanis Ardian Prasetyo. Masters Program in Hospital Management, Universitas Muhammadiyah, Yogyakarta, Jl. Lingkar Selatan, Tamantirto, Kasihan, Bantul, Yogyakarta. Email: dhanisardian@gmail.com. Mobile: 082216579779
\end{abstract}

